\title{
Kinetics of enzymatic hydrolysis of polysaccharide-rich particulates
}

\author{
Pin-Jing $\mathrm{He}^{\mathrm{a}, 1}$, Fan Lü ${ }^{\mathrm{a}, 2}$, Li-Ming Shao ${ }^{\mathrm{a}, 3}$, Xiu-Jiang Pan ${ }^{\mathrm{a}, 4}$, Duu-Jong Lee ${ }^{\mathrm{b}, 5, *}$ \\ ${ }^{\text {a }}$ State Key Laboratory of Pollution Control \& Resource Reuse, Tongji University, Shanghai 200092, China \\ ${ }^{\mathrm{b}}$ Department of Chemical Engineering, National Taiwan University, Taipei 106, Taiwan \\ Received 5 December 2005; accepted 3 July 2006
}

\begin{abstract}
Both $\mathrm{pH}$ and volatile fatty acid (VFA) inhibit the hydrolysis of particulate organic waste. It is not clear yet whether VFA or pH is the dominant factor in hydrolysis inhibition. The effects of $\mathrm{pH}$ and acetate on the enzymatic hydrolysis of potato samples containing mainly carbohydrate were studied at fixed $\mathrm{pH}$ values (5-9) and with/without $20 \mathrm{~g} \mathrm{~L}^{-1}$ acetate. The leaching liquors were refreshed at prescribed intervals. Experimental results showed that both $\mathrm{pH}$ and acetate influenced the hydrolysis of carbohydrate, but that $\mathrm{pH}$ was more influential than acetate.

Numerous kinetic models could fit the hydrolysis data during the first $40 \mathrm{~h}$ of hydrolysis when inhibitive effects were not significant. The simplified Chen-Hashimoto model, $-\mathrm{d} S / \mathrm{d} t=K_{\mathrm{H}} S /\left(K_{\mathrm{S}}\left(S_{0}-S\right)+S\right)$, closely fit all of the experimental data. Also, the fitting achieved by applying the non-competitive inhibition model $\left(K_{\mathrm{H}}=K_{\mathrm{H}}^{0} /\left(1+\mathrm{I} / K_{\mathrm{I}}\right)\right)$ on three inhibitors $\left(\mathrm{H}^{+}, \mathrm{OH}^{-}\right.$, total/undissociated/dissociated acetate $)$was excellent for carbohydrate hydrolysis.
\end{abstract}

(C) 2007 Taiwan Institute of Chemical Engineers. Published by Elsevier B.V. All rights reserved.

Keywords: pH value; Acetate; Enzymatic hydrolysis; Inhibition; Particulate organic waste; Kinetic models

\section{Introduction}

Substrate hydrolysis is achieved with extracellular hydrolytic enzymes excreted by fermentative microorganisms, whose essential metabolism, called acidogenesis, yields various metabolites, including volatile fatty acids (VFA), lactate, alcohols, ammonia, and other monomeric substances, which change the suspension's pH (Horiuchi et al., 2002; Lata et al., 2002; Traverso et al., 2000; Zoetemeyer et al., 1982). Both the suspension $\mathrm{pH}$ and acidogenic products influence microbial activity in an anaerobic environment (Aguilar et al., 1995; Barredo and Evison, 1991; Batstone et al., 2002; Mladenovska and Ahring, 2000; Mösche and Jördening, 1998, 1999; Pind et al., 2003a). The very complex nature of the interactions between organic substances and $\mathrm{pH}$ makes predicting the inhibitory levels of acidogenic products difficult, if not impossible (Pind et al., 2003b).

\footnotetext{
* Corresponding author. Tel.: +88622362 5632; fax: +886223623040.

E-mail address: djlee@ntu.edu.tw (D.-J. Lee).

1 何品晶

2 呂凡

3 邵立明

4 潘修疆

${ }^{5}$ 李篤中
}

Some studies have addressed the effects of $\mathrm{pH}$ and acidogenic products on the hydrolysis of substrates. Palenzuela-Rollón (1999) stated that $\mathrm{pH}$ did not significantly affect the rate of hydrolysis of protein-rich wastewater from fish processing when the $\mathrm{pH}<8$. Boon found that the optimal $\mathrm{pH}$ in the hydrolysis of primary sludge was 6.5 (as reviewed by Sanders et al., 2002). Elefsiniotis et al. (1996) found that reducing the $\mathrm{pH}$ from 5.1 to 4.5 did not influence the hydrolysis or rate of acidogenesis of primary sludge, while an increase in $\mathrm{pH}$ from 5.1 to 6.1 increased the rate of hydrolysis but reduced the rate of acidogenesis. Veeken et al. (2000) were the first to evaluate separately the roles of $\mathrm{pH}$, total VFA, and undissociated VFA in the hydrolysis of biowaste. Their statistical analysis of data obtained at $\mathrm{pH}$ 5-7 showed that the rate of hydrolysis depended on the $\mathrm{pH}$ value, but was not related to the total VFA (3-30 g-COD L ${ }^{-1}$ ) or the undissociated VFA. Babel et al. (2004) found that adding anaerobic inoculums reduced the amount of volatile solids in pineapple samples by $42 \%$ at $2500 \mathrm{mg} \mathrm{L}^{-1}$ VFA and by $48 \%$ at $5000 \mathrm{mg} \mathrm{L}^{-1}$ VFA at $\mathrm{pH}$ 6.5-7.5. Restated, VFA did not affect the rate of hydrolysis. Zou et al. (2003) and Veeken and Hamelers (2000) observed a decline in the hydrolysis rate caused by the accumulation of VFA. González et al. (2005) found that the hydrolysis of soluble protein was completely inhibited when the concentration of acetate exceeded 


\begin{tabular}{|c|c|}
\hline \multicolumn{2}{|c|}{ Nomenclature } \\
\hline$A$ & exponent in the $A$-order biomass kinetic equation \\
\hline$B$ & concentration of biomass or enzyme $\left(\mathrm{mol} \mathrm{L}^{-1}\right)$ \\
\hline $\begin{array}{l}f_{\mathrm{h}} \\
{\left[\mathrm{H}^{+}\right]}\end{array}$ & $\begin{array}{l}\text { biodegradable fraction of the substrate } \\
\text { concentration of hydronium ion }\left(\mathrm{mol} \mathrm{L}^{-1}\right)\end{array}$ \\
\hline$H_{\mathrm{S}}$ & hydrolytic flux, g-dry solid $\left(\mathrm{cm}^{-2} \mathrm{~h}^{-1}\right)$ \\
\hline & $\begin{array}{l}\text { saturation constant for biomass or enzyme } \\
\left(\mathrm{mol} \mathrm{L}^{-1}\right)\end{array}$ \\
\hline$K_{\mathrm{H}}$ & hydrolysis rate constant $\left(\mathrm{h}^{-1}\right)$ \\
\hline$K_{\mathrm{H}}^{0}$ & hydrolysis rate constant without inhibition $\left(\mathrm{h}^{-1}\right)$ \\
\hline & $\begin{array}{l}\text { inhibition constant for the } i \text { inhibitory agent } \\
\left(\mathrm{mol} \mathrm{L}^{-1}\right)\end{array}$ \\
\hline$K_{\mathrm{S}}$ & saturation constant for the substrate $\left(\mathrm{mol} \mathrm{L}^{-1}\right)$ \\
\hline & specific hydrolysis rate constant $\left(\mathrm{h}^{-1}\right)$ \\
\hline $\begin{array}{l}\mathrm{I}_{i} \\
{\left[\mathrm{OH}^{-}\right]}\end{array}$ & $\begin{array}{l}\text { concentration of the } i \text { inhibitory agent }\left(\mathrm{mol} \mathrm{L}^{-1}\right) \\
\text { concentration of hydroxyl ion }\left(\mathrm{mol} \mathrm{L}^{-1}\right)\end{array}$ \\
\hline & radius of a particle at time $t\left(\mathrm{~cm}^{-1}\right)$ \\
\hline & initial radius of a particle $\left(\mathrm{cm}^{-1}\right)$ \\
\hline$S$ & substrate concentration $\left(\mathrm{mol} \mathrm{L}^{-1}\right)$ \\
\hline & initial substrate concentration $\left(\mathrm{mol} \mathrm{L}^{-1}\right)$ \\
\hline$S_{\text {surf }}$ & surface area of the organic solid $\left(\mathrm{cm}^{2}\right)$ \\
\hline & time $(\mathrm{h})$ \\
\hline$v$ & hydrolysis rate $\left(\mathrm{mol} \mathrm{L}^{-1} \mathrm{~h}^{-1}\right)$ \\
\hline$v_{\max }$ & maximal hydrolysis rate $\left(\mathrm{mol} \mathrm{L}^{-1} \mathrm{~h}^{-1}\right)$ \\
\hline & $\begin{array}{l}\text { growth yield coefficient (g-dry cell } \mathrm{g}^{-1} \text {-sub- } \\
\text { strate) }\end{array}$ \\
\hline \multicolumn{2}{|c|}{ Greek symbols } \\
\hline & exponent \\
\hline$\mu_{\max }$ & maximum specific growth rate $\left(\mathrm{h}^{-1}\right)$ \\
\hline & density of the organic solid $\left(\mathrm{g} \mathrm{cm}^{-3}\right)$ \\
\hline$\phi$ & $\begin{array}{l}\text { dimensionless particle radius, equal to the ratio of } \\
\text { the radius of the particle at time } t \text { to the initial } \\
\text { radius of the particle }\end{array}$ \\
\hline
\end{tabular}

$1000 \mathrm{mg} \mathrm{L}^{-1}$. Anaerobic Digestion Model No. 1 (ADM1) revealed that $\mathrm{pH}$ could inhibit hydrolysis, if required (Batstone et al., 2002). However, ADM1 did not incorporate the $\mathrm{pH}-$ dependent inhibition of hydrolysis by acidogenic products.

Numerous kinetic models have been used to describe the hydrolytic kinetics same of them are listed in Table 1. In fact, these hydrolytic models were effective for the data by the corresponding authors and were sometimes equivalent to each other in effectiveness or essence (Cecchi et al., 1990; Valentini et al., 1997; Vavilin et al., 1996). For example, if the $\mu_{\max }$ and $Y$ in the Monod equation is taken as being constant, then it has the same form as the Monod and Michaelis-Menten equations. The Haldane equation can be expressed as $-\mathrm{d} S / \mathrm{d} t=k_{\mathrm{H}} B /\left(1+K_{\mathrm{S}} /\right.$ $\left.S+S / K_{\mathrm{I}}\right)$. Also, the shrinking core model, flux model, and surface based kinetics model can all be expressed in the same form $S_{0}^{1 / 3}-S^{1 / 3}=\int B \mathrm{~d} t$, where $S_{0}, S$, and $B$ were the initial substrate concentration, substrate concentration, and biomass concentration, respectively.

Many inhibitive mechanisms have been proposed for biological processes, but discussion of the inhibition of the hydrolysis of biowaste has been limited. The effect of $\mathrm{pH}$ on hydrolysis was usually qualitatively described or empirically linearly regressed with data (Veeken et al., 2000). The noncompetitive inhibition model, $K_{\mathrm{H}}=K_{\mathrm{H}}^{0} /\left(1+\mathrm{I} / K_{\mathrm{I}}\right)$, was applied by Angelidaki et al. (1999) and González et al. (2005) to interpret their hydrolysis data. González et al. (2005) found that Levenspiel model, $K_{\mathrm{H}}=K_{\mathrm{H}}^{0} /\left(1-\mathrm{I} / K_{\mathrm{I}}\right)$, and Luong model, $K_{\mathrm{H}}=K_{\mathrm{H}}^{0} /\left(1-\left(\mathrm{I} / K_{\mathrm{I}}\right)^{\gamma}\right)$, could fit their data. Competitive or incompetitive inhibitions, however, have seldom been applied in hydrolysis studies.

The above-cited works indicate that the effects of suspension $\mathrm{pH}$ and VFA on substrate hydrolysis and acidogenesis have not been conclusively determined. More works on substrate hydrolysis and bioreactor design and operation were recently published (Chen, 2006; Chen et al., 2006; Huang, 2005; Hwang et al., 2005; Kao et al., 2006; Lan et al., 2005; Lin et al., 2005; Liu et al., 2004; Ng and Tsai, 2005; Ruaan and Yu, 2004; Su et al., 2006). In particular, hydrolysis often occurs together with acidogenesis, and the products of the latter further inhibit the hydrolysis of the substrate, making data interpretation more difficult. It is not clear yet whether VFA or $\mathrm{pH}$ is the dominant factor in hydrolysis inhibition. In this study, we sought to find out how the $\mathrm{pH}$ and the amount of acetate, one major acidogenic product, influence the enzymatic hydrolysis of particulate organic waste. The kinetic equations frequently accepted in the literature were tested to determine their fit with the hydrolysis data, in order to demonstrate the inhibition kinetics of this system

\section{Materials and methods}

\subsection{Materials}

Fresh potato, the testing substrate, was cut into cubes 2 $3 \mathrm{~mm}$ in size and stored at $4{ }^{\circ} \mathrm{C}$ for $12-24 \mathrm{~h}$. Each potato sample

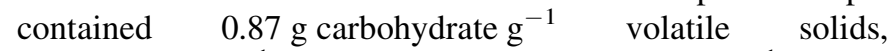

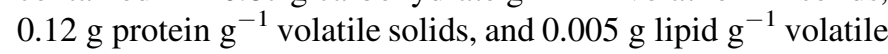
solids.

Hydrolysis enzymes were extracted from the returned activated sludge in the secondary treatment stage of a municipal wastewater treatment plant. The sludge was gravitationally precipitated for $30 \mathrm{~min}$, and the supernatant was discarded. The residual sludge was centrifuged at $1000 \times g$ for $30 \mathrm{~min}$, and the supernatant was again discarded. The residual sludge was washed with an equal volume of $0.9 \% \mathrm{NaCl}$ solution and centrifuged at $1000 \times g$ for another $30 \mathrm{~min}$, with the sludge cake collected. Five hundred grams of the collected sludge cake was mixed with $2000 \mathrm{~mL}$ potassium phosphate buffer $\left(\mathrm{pH} 7.2,0.1 \mathrm{~mol} \mathrm{~L}^{-1}\right)$ and then allowed to settle for $1 \mathrm{~h}$ at room temperature with frequent agitation. The aqueous phase, i.e., here referred to as the enzymatic extracts, was recovered through centrifugation at $1200 \times g$ for $30 \mathrm{~min}$. The activities of $\alpha$-amylase and protease were measured. The former was found to be $72.6 \mathrm{U} \mathrm{L}^{-1}$, while the latter was not detected in this extract. It was found that the activities of hydrolytic enzymes could hydrolyze the solid substrates (Goel et al., 1998). 
Table 1

Kinetic models in the literature for describing hydrolysis

\begin{tabular}{|c|c|c|}
\hline Name & Expression & References \\
\hline Chemical first-order & $-\mathrm{d} S / \mathrm{d} t=K_{\mathrm{H}} S$ & Eastman and Ferguson (1981) \\
\hline Biological first-order & $-\mathrm{d} S / \mathrm{d} t=k_{\mathrm{H}} S B$ & Valentini et al. (1997) \\
\hline Half-order biomass kinetic & $-\mathrm{d} S / \mathrm{d} t=k_{\mathrm{H}} S B^{0.5}$ & Rozzi and Verstraete (1981) \\
\hline$A$-order biomass kinetic & $-\mathrm{d} S / \mathrm{d} t=k_{\mathrm{H}} S X^{A}$ & Valentini et al. (1997) \\
\hline Michaelis-Menten equation & $-\mathrm{d} S / \mathrm{d} t=k_{\mathrm{H}} S B /\left(K_{\mathrm{S}}+S\right)$ & Valentini et al. (1997) \\
\hline Monod equation & $-\mathrm{d} S / \mathrm{d} t=\mu_{\max } S B /\left(Y\left(K_{\mathrm{S}}+S\right)\right)$ & Hobson (1983) \\
\hline Haldane equation & $-\mathrm{d} S / \mathrm{d} t=\mu_{\max } B /\left(Y\left(1+K_{\mathrm{S}} / S+S / K_{i}\right)\right)$ & Andrews and Graef (1971) \\
\hline Contois model & $-\mathrm{d} S / \mathrm{d} t=k_{\mathrm{H}} S B /\left(K_{\mathrm{S}} B+S\right)$ & Henze (1995) \\
\hline Chen-Hashimoto model & $-\mathrm{d} S / \mathrm{d} t=k_{\mathrm{H}} S B /\left(K_{\mathrm{S}}\left(S_{0}-S\right)+S\right)$ & Chen and Hashimoto (1980) \\
\hline Two phase model & $-\mathrm{d} S / \mathrm{d} t=k_{\mathrm{H}} S B /\left(\left(K_{\mathrm{S}}+S\right)\left(K_{\mathrm{B}}+B\right)\right)$ & Vavilin et al. (1996) \\
\hline Step diffusion equation & $-\mathrm{d} S / \mathrm{d} t=\left[v_{\max }^{2}+K_{\mathrm{H}}\left(S_{0}-S\right)\right]^{1 / 2}$ & Cecchi et al. (1990) \\
\hline Shrinking core model & $\begin{array}{l}-\mathrm{d} S / \mathrm{d} t=3 k_{\mathrm{H}} S_{0} \phi^{2} B \\
-\mathrm{d} \phi / \mathrm{d} t=k_{\mathrm{H}} B\end{array}$ & Negri et al. (1993) \\
\hline Flux model & $-\mathrm{d} S / \mathrm{d} t=k_{\mathrm{H}} S_{\text {surf }} B \rho$ & Terashima and Lin (2000) \\
\hline Surface based kinetics model & $-\mathrm{d} S / \mathrm{d} t=k_{\mathrm{H}} S_{\text {surf }}$ & Sanders et al. (2000) \\
\hline
\end{tabular}

\subsection{Hydrolysis tests}

Two batches of hydrolysis tests with different concentrations of added acetate were conducted. The batch I tests were conducted using leaching liquor at fixed $\mathrm{pH}$ values and recorded as I-pH 5 to I-pH 9, while the batch II tests were conducted at fixed $\mathrm{pH}$ values with liquors containing externally dosed acetate of $20 \mathrm{~g} \mathrm{~L}^{-1}$ and recorded as II-pH 5 to II-pH 9. For batch I, every $50 \mathrm{~mL}$ of leaching liquor consisted of $5 \mathrm{~mL}$ of enzymatic extracts and $45 \mathrm{~mL}$ of $0.1 \mathrm{~mol} \mathrm{~L}^{-1}$ phosphate buffers. For batch II, every $50 \mathrm{~mL}$ of leaching liquor consisted of $5 \mathrm{~mL}$ of enzymatic extracts and $45 \mathrm{~mL}$ of acetate buffers.

In each test, samples containing $20 \mathrm{~g}$ of wet potato were wrapped in gauze bags (80-mesh) and hung in bottles with 50$\mathrm{mL}$ of leaching liquor. The bottles were shaken at $100 \mathrm{rpm}$, and the temperature was kept at $37 \pm 0.2{ }^{\circ} \mathrm{C}$. The leaching liquor was replaced with fresh liquor (containing enzyme extracts, dosed acetates, etc.) after 4, 8, 12, 16, 24, 32, 40, 48, 60, 72, 96, and $144 \mathrm{~h}$ of hydrolysis, respectively. In each liquor replacement, the changes in $\mathrm{pH}$ and the acetate level of the suspension were regarded as minimal.

\subsection{Analytic methods}

The collected leaching liquors were filtered using $0.45 \mu \mathrm{m}$ polyester film and measured to determine the $\mathrm{pH}$, the amount of dissolved carbon, dissolved nitrogen, reducing sugar, and amino acid. The suspension $\mathrm{pH}$ was measured with a $\mathrm{pH}$ meter (OAKTON, USA). Dissolved carbon and dissolved nitrogen were measured with a $\mathrm{TN}_{\mathrm{b}} / \mathrm{TC}$ multi N/C 3000 Analyzer (Analytik Jena AG, Germany). Reducing sugar was spectrophotometrically determined using the 3,5-dinitrosalicylic acid (DNS) method (Miller, 1956). The Lowry method was used to determine the amount of amino acid (Lowry et al., 1951). After $144 \mathrm{~h}$ of testing, the potato particulates were removed from the gauze bags and tested.

The total amount of carbohydrate in the substrate was determined with the method described by Mösche and Jördening (1999) with glucose used as a standard. The total amount of proteins was determined with the Lowry method (Lowry et al., 1951), and that of lipid was gravimetrically determined by the Soxlett extraction (APHA, 1998). The $\alpha-$ amylase activity of the enzymatic extracts was assayed according to Bernfeld (1955). One unit (U) of $\alpha$-amylase activity was defined as the amount of enzyme that released $1 \mathrm{mmol} \mathrm{L}^{-1}$ of reducing sugar, equivalent to maltose, per min. The protease activity was determined using casein as a substrate according to the method of McDonald and Chen (1965). One unit $(\mathrm{U})$ of protease activity was defined as the amount of enzyme that released $1 \mathrm{mg} \mathrm{L}^{-1}$ of tyrosine per min.

\section{Results and discussion}

\subsection{Particulate hydrolysis}

The $0.45 \mu \mathrm{m}$ filtered, dissolved carbon of leaching liquors was cumulated to access the total organic carbon hydrolyzed into aqueous phase (Fig. 1).

With regular replacement of leaching liquors, one may assume that hydrolysis will proceed until only residues are left. However, this was not the case in the test. The cumulative dissolved carbon approached a saturated value. This phenomenon suggested structural transformation might have happened to the solid substrate, a factor that was not under control during the reaction (Gallant et al., 1997). The total hydrolyzed dissolved carbon of batch I was higher than that of batch II with $20 \mathrm{~g} \mathrm{~L}^{-1}$ of added acetate at a corresponding $\mathrm{pH}$, indicating the inhibitive role of acetate. The cumulative dissolved carbon of batch I and batch II followed the descending sequence $\mathrm{pH}$ $7>$ pH $8>$ pH $9>$ pH $6>$ pH 5; i.e., $\mathrm{pH} 7$ was preferable for enzymatic hydrolysis, and the inhibition caused by $\mathrm{pH}$ was weak in the alkali solution.

The generation rate of reducing sugar in batch reactors represented the amylase activity in the suspension. The total amount of produced reducing sugar (RS) of batch I without acetate fell within $1500-3200 \mathrm{mg}^{-} \mathrm{C} \mathrm{L}^{-1}$. The production rate $\mathrm{dRS} / \mathrm{d} t$ followed the sequence $\mathrm{pH} 7>\mathrm{pH} \quad 8>\mathrm{pH}$ $9>\mathrm{pH} 5 \approx \mathrm{pH} 6$ as shown in Fig. 2, which is consistent 


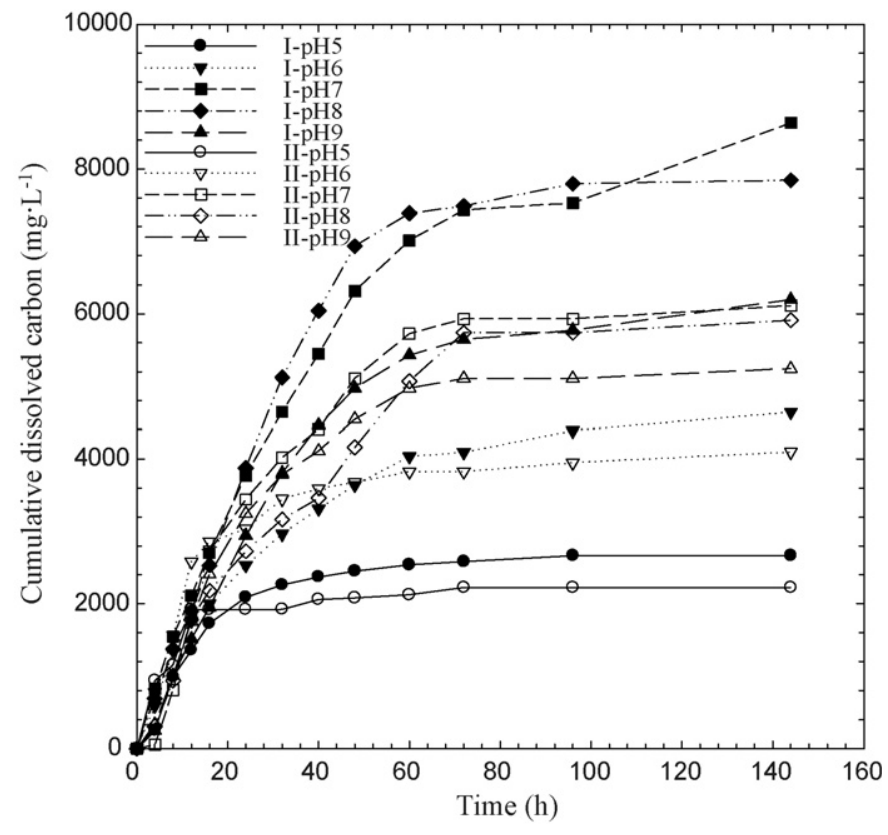

Fig. 1. The cumulative dissolved carbon with or without acetate addition at different $\mathrm{pH}$ values.

with the cumulative dissolved carbon result (Fig. 1). The amount of produced reducing sugar of batch II with $20 \mathrm{~g} \mathrm{~L}^{-1}$ acetate within $1000-2000 \mathrm{mg}-\mathrm{C} \mathrm{L}^{-1} . \mathrm{dRS} / \mathrm{d} t$ followed the sequence $\mathrm{pH} 5>\mathrm{pH} 7>\mathrm{pH} 6>\mathrm{pH} 8>\mathrm{pH}$ 9, but the difference among the $\mathrm{dRS} / \mathrm{d} t$ data sets was not obvious.

In all of the batches, $\mathrm{dRS} / \mathrm{d} t$ gradually decreased with time to zero, indicating that enzymes were not efficient during the latter period of hydrolysis.

\subsection{Effects of $p H$ and acetate on the hydrolysis of carbohydrate}

The data for I-pH 7 (i.e., $\mathrm{pH} 7$ and without acetate) were used to compare the hydrolysis efficiency. The hydrolysis of carbohydrate was indicated by the change in the dissolved carbon content: the quantity of hydrolyzed carbon was $30 \%$ less at pH 7 with $20 \mathrm{~g} \mathrm{~L}^{-1}$ of extrinsic acetate, $10-12 \%$ or $36 \%$ less at $\mathrm{pH}>7$ without acetate or a high acetate concentration, respectively, and 50 or $60 \%$ less at $\mathrm{pH} 5$ without or with high concentrations of acetate, respectively. Dissociated acetate dominated at $\mathrm{pH}>6$. Therefore, $10^{-5} \mathrm{~mol} \mathrm{~L}{ }^{-1}\left[\mathrm{H}^{+}\right]$inhibited carbohydrate hydrolysis by approximately $50 \%$, while $20 \mathrm{~g} \mathrm{~L}^{-1}$ of dissociated acetate inhibited carbohydrate hydrolysis by $30 \%$. Additionally, undissociated acetate did no noticeably inhibit carbohydrate hydrolysis.

\subsection{Kinetic model}

The carbon in the particulate sample was the substrate to be hydrolyzed. The amount of solid carbon was determined as the initial quantity of solid carbon minus the amount of dissolved carbon in the aqueous phase. Since the same quantity of enzymatic extracts was added during the refreshment of leaching liquors, the activity of enzyme $(B)$ could be regarded
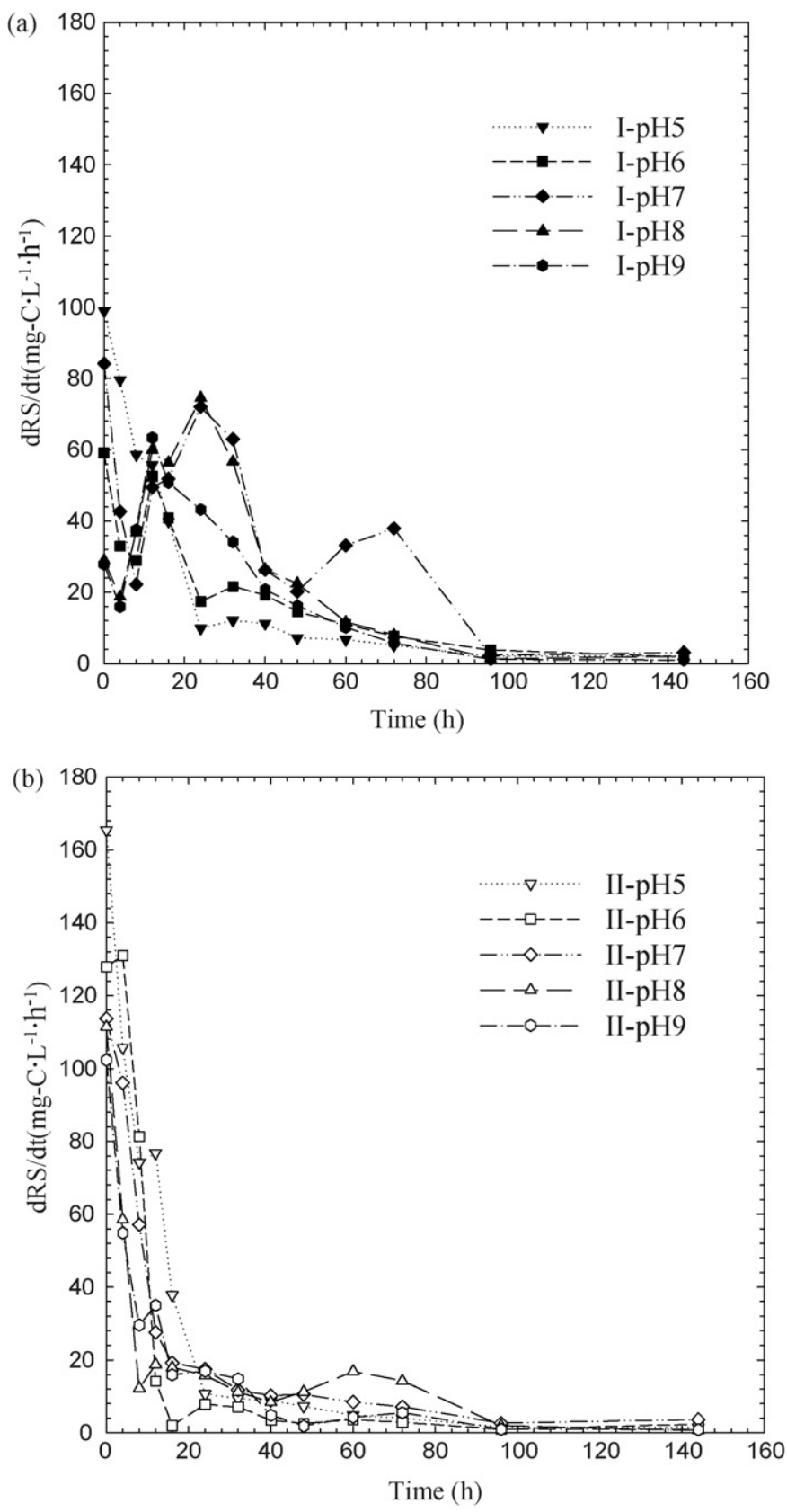

Fig. 2. The rate of production of reducing sugar (dRS/dt) of (a) batch I and (b) batch II.

as being constant. However, as revealed in Fig. 2, the generation rate of reducing sugar, which represented the in situ enzymatic activity according to the definition of $\alpha$-amylase (Bernfeld, 1955), was not stable. Thus, the concentration of $B$ was determined under either constraint: $B=$ constant or $B=$ the generation rate of reducing sugar.

Under constant $B$, the biological first-order and $A$-order biomass kinetics correspond to a first-order chemical reaction with the kinetics $-\mathrm{d} S / \mathrm{d} t=K_{\mathrm{H}} S$. The Michaelis-Menten, Monod, Contois and two-phase models use $-\mathrm{d} S / \mathrm{d} t=K_{\mathrm{H}} S /\left(K_{\mathrm{S}}+S\right)$. Of all the kinetic models tested here, the Chen-Hashimoto model most closely fitted the original data $\left(R^{2}=0.999\right)$, followed by the step diffusion model $\left(R^{2}=0.994\right)$. Other models fitted in the first 
$40 \mathrm{~h}$ but not thereafter because the inhibitive effects increased with time. Nonlinear regressions of the tested models were conducted to obtain a least-squares fit to all of the kinetic data. The chemical first-order and flux model yielded unsatisfactory $R^{2}$ values of 0.860 and 0.849 , respectively. Although the Michaelis-Menten and Haldane equations exhibited a high $R^{2}$ value of over 0.99 , negative kinetic parameters, which lack physical meaning, were obtained. Roques et al. (1982) also asserted that anomalies may arise when the saturation constant $K_{\mathrm{S}}$ in the Monod model is determined by fitting because it is not a true constant but depends on the age of the sludge and the total amount of biomass in the reactor.

Sanders et al. (2002) considered the effect of the biodegradability of the substrate in the model of hydrolysis by introducing a constant parameter - the biodegradable fraction $f_{\mathrm{h}}$. Fitting the chemical reaction by means of a first-order equation improved $R^{2}$ from 0.860 to 0.980 at $f_{\mathrm{h}}=0.32$. However, as indicated by the saturation value of dissolved carbon in Fig. 1, for an initial substrate concentrate $S_{0}$ of $27 \mathrm{~g} \mathrm{~L}^{-1}$, the regressed $f_{\mathrm{h}}$ value ranged from 0.08 to 0.32 , so the value was not constant as proposed but depended on the $\mathrm{pH}$ and the amount of acetate.

When the non-linear regressions were conducted, using the rate of generation of the reducing sugar measured in Fig. 2 as the concentration of the enzyme, the regression coefficient $R^{2}$ of the biological first-order and half-order kinetics and in the flux model were improved to 0.979, 0.946, and 0.980, respectively. The improvement in the fitting was attributable to the slow drop in the rate of generation of reducing sugar, so the simulated substrate concentration approached an asymptote. The Michaelis-Menten, two-phase and Haldane models produced negative or overly large fitted parameters. The ChenHashimoto model yielded a high $R^{2}$ value of 0.999 . The Contois model yielded a $R^{2}$ value of 0.862 and reasonable kinetic parameters, so fitting was much better than that at a constant $B$, which yielded negative parameters.

Table 2 lists the best-fit parameters of the Chen-Hashimoto model and the step-diffusion model in all of the tests at constant $B$. The Chen-Hashimoto model fitted all of the tests with high $R^{2}$ value (>0.998). Also, the fitted saturation constant $K_{\mathrm{S}}$ was
$1.04 \pm 0.00192$, so one parameter, the hydrolysis constant $K_{\mathrm{H}}$, sufficed to characterize the process. However, the step diffusion model could not fit tests with acetate at $\mathrm{pH} 5$ or 6 , where hydrolysis was severely inhibited. Also, the obtained fitted parameters, $K_{\mathrm{H}}$ and $v_{\max }$, followed no clear trend under various $\mathrm{pH}$ values. Therefore, the simplified Chen-Hashimoto model, $-\mathrm{d} S / \mathrm{d} t=K_{\mathrm{H}} S /\left(K_{\mathrm{S}}\left(S_{0}-S\right)+S\right)$, was suitable for modeling the hydrolysis data.

The best-fit of the Chen-Hashimoto model indicated a possible substrate limit in the test, with emphasis of the influence of the initial concentration of the substrate $\left(S_{0}\right)$. In the present tests, the cumulative dissolved carbon of all of the batches progressed to an asymptote (Fig. 1), and the enzymatic activity (indicated by the generation rate of reducing sugar, Fig. 2) to a void, indicating impaired biodegradability or limited availability of the substrate, although the concentration of the substrate remained high enough.

The competitive or incompetitive models indicated that the inhibition resulted in a fluctuating saturation constant, $K_{\mathrm{S}}$. However, Table 3 shows that all of the best-fitted $K_{\mathrm{S}}$ values were close to each other. Therefore, these two inhibition mechanisms can be excluded from our discussion.

Fitting using the combined non-competitive inhibition model of three inhibitors (1st: $\mathrm{H}^{+}, 2 \mathrm{nd}: \mathrm{OH}^{-}$, 3rd: total/ undissociated/dissociated acetate) yielded an $R^{2}$ value of greater than 0.9 . The model showed a combination of inhibition by organic acid and independent, non-competitive inhibition by $\mathrm{H}^{+}$and $\mathrm{OH}^{-}$ions. Restated, hydrolysis was inhibited by three inhibitors: $\mathrm{H}^{+}, \mathrm{OH}^{-}$, and organic acid, each followed a noncompetitive inhibition mechanism. The inhibitory effects of total acetate were also significant. Some model fitting schemes were noted by Mösche and Jördening (1999).

Table 3 lists the corresponding kinetic parameters. The concentrations of undissociated, dissociated, and total acetate needed to inhibit hydrolysis were 61,9490 , and $9615 \mathrm{mg} \mathrm{L}^{-1}$, respectively. Other inhibitive models, including those of noncompetitive inhibition using one or two inhibitors, such as the Levenspiel model or the Luong model, failed to model the effects of $\mathrm{pH}$ and acetate simultaneously.

Table 2

Kinetic parameters of the Chen-Hashimoto model and step diffusion model of the hydrolysis of carbohydrate ${ }^{\mathrm{a}}$

\begin{tabular}{|c|c|c|c|c|c|c|}
\hline & $\mathrm{pH}$ & 5 & 6 & 7 & 8 & 9 \\
\hline \multicolumn{7}{|c|}{ Chen-Hashimoto model of carbohydrate hydrolysis } \\
\hline \multirow[t]{3}{*}{ Without acetate } & $R^{2}$ & 0.999 & 0.999 & 0.999 & 0.998 & 0.999 \\
\hline & $K_{\mathrm{H}}\left(\mathrm{h}^{-1}\right)$ & $1.06 E-05$ & $7.93 E-05$ & $3.86 E-04$ & $2.04 E-04$ & $1.44 E-04$ \\
\hline & $K_{\mathrm{S}}$ & $1.04 E+00$ & $1.04 E+00$ & $1.04 E+00$ & $1.04 E+00$ & $1.04 E+00$ \\
\hline \multirow[t]{3}{*}{ With $20 \mathrm{~g} \mathrm{~L}^{-1}$ acetate } & $R^{2}$ & 0.999 & 0.999 & 0.999 & 0.999 & 0.999 \\
\hline & $K_{\mathrm{H}}\left(\mathrm{h}^{-1}\right)$ & $1.17 E-05$ & $3.02 E-05$ & $1.23 E-04$ & $1.35 E-04$ & $7.69 E-05$ \\
\hline & $K_{\mathrm{S}}$ & $1.04 E+00$ & $1.04 E+00$ & $1.04 E+00$ & $1.04 E+00$ & $1.04 E+00$ \\
\hline \multicolumn{7}{|c|}{ Step diffusion model of carbohydrate hydrolysis } \\
\hline \multirow[t]{3}{*}{ Without acetate } & $R^{2}$ & 0.757 & 0.915 & 0.975 & 0.977 & 0.975 \\
\hline & $K_{\mathrm{H}}\left(\mathrm{h}^{-1}\right)$ & $1.49 E-03$ & $1.90 E-03$ & $2.82 E-03$ & $3.35 E-03$ & $2.36 E-03$ \\
\hline & $v_{\max }$ & $6.96 E-02$ & $9.79 E-02$ & $1.58 E-01$ & $1.72 E-01$ & $1.25 E-01$ \\
\hline \multirow[t]{3}{*}{ With $20 \mathrm{~g} \mathrm{~L}^{-1}$ acetate } & $R^{2}$ & 0.081 & 0.617 & 0.958 & 0.981 & 0.940 \\
\hline & $K_{\mathrm{H}}\left(\mathrm{h}^{-1}\right)$ & $1.41 E-03$ & $2.27 E-03$ & $2.64 E-03$ & $2.07 E-03$ & $2.46 E-03$ \\
\hline & $v_{\max }$ & $6.33 E-02$ & $1.08 E-01$ & $1.34 E-01$ & $1.14 E-01$ & $1.22 E-01$ \\
\hline
\end{tabular}

\footnotetext{
a $95 \%$ confidence interval.
} 
Table 3

Kinetic parameters of combined non-competitive inhibition of $\mathrm{pH}$ and acetate in the hydrolysis of carbohydrate ${ }^{\mathrm{a}}$

\begin{tabular}{|c|c|c|c|c|}
\hline \multirow[t]{2}{*}{ Inhibitor } & \multicolumn{3}{|l|}{ Carbohydrate } & \multirow{2}{*}{$\begin{array}{l}\text { Protein } \\
\mathrm{H}^{+}, \mathrm{OH}^{-}, \mathrm{HAc}\end{array}$} \\
\hline & $\mathrm{H}^{+}, \mathrm{OH}^{-}, \mathrm{HAc}$ & $\mathrm{H}^{+}, \mathrm{OH}^{-}, \mathrm{Ac}^{-}$ & $\mathrm{H}^{+}, \mathrm{OH}^{-}$, total acetate & \\
\hline$R^{2}$ & 0.899 & 0.930 & 0.930 & 0.797 \\
\hline$K_{\mathrm{H}}^{0}\left(\mathrm{~h}^{-1}\right)$ & $1.50 E-03$ & $1.51 E-03$ & $1.51 E-03$ & $2.30 E-05$ \\
\hline$K_{\mathrm{I}, \mathrm{H}}^{+}\left(\mathrm{mol} \mathrm{L}^{-1}\right)$ & $1.50 E-07$ & $1.23 E-07$ & $1.23 E-07$ & $2.51 E-05$ \\
\hline$K_{\mathrm{I}, \mathrm{OH}}^{-}\left(\mathrm{mol} \mathrm{L}^{-1}\right)$ & $6.68 E-08$ & $8.14 E-08$ & $8.11 E-08$ & $3.57 E-08$ \\
\hline$K_{\mathrm{I}}$,acetate $\left(\mathrm{mol} \mathrm{L}^{-1}\right)$ & $1.18 E-03$ & $1.93 E-01$ & $1.95 E-01$ & $3.56 E-05$ \\
\hline
\end{tabular}

a $95 \%$ confidence interval.

Based on this inhibition model, using undissociated acetic acid or dissociated acetate as an inhibitor, an acetate level below 12,600 or $17,400 \mathrm{mg} \mathrm{L}^{-1}$ would not markedly affect carbohydrate hydrolysis at $\mathrm{pH}$ values between 5.9 and 7.7, respectively.

\section{Conclusion}

This work examined the effects of $\mathrm{pH}$ and the acetate concentration on the enzymatic hydrolysis of potato samples which contained $87 \%$ carbohydrate and $12 \%$ protein, at $37^{\circ} \mathrm{C}$. Replacing the leaching liquors at fixed $\mathrm{pH}(5-9)$ and acetate levels $\left(0\right.$ or $\left.20 \mathrm{~g} \mathrm{~L}^{-1}\right)$, yielded separate rates for the hydrolysis of carbohydrate in potato and revealed the possible inhibitive effects of $\mathrm{pH}$ and acetate.

The drop in the amount of volatile solids was maximal at neutral $\mathrm{pH}$, without or with $20 \mathrm{~g} \mathrm{~L}^{-1}$ acetate. The amounts of cumulative dissolved carbon in both tests of the effect on $\mathrm{pH}$ followed the order $\mathrm{pH} 7>\mathrm{pH} 8>\mathrm{pH} 9>\mathrm{pH} 6>\mathrm{pH} 5$.

The Chen-Hashimoto model and the step diffusion model correlated with the kinetic hydrolysis data. Introducing a correction factor, such as substrate biodegradability, or considering the change in enzyme activity during the test, improved the model fitting. The non-competitive inhibitive model with three inhibitors $\left(\mathrm{H}^{+}, \mathrm{OH}^{-}\right.$, total/undissociated/ dissociated acetate) best fit the inhibition of carbohydrate hydrolysis.

\section{Acknowledgement}

This work was financially supported by the National HiTech Research and Development Program of China (program no. 2001AA644010, no. 2003 AA644020 and no. 50538080, PR China) and Project of National Natural Science Foundation of China (no. 50578115).

\section{References}

Aguilar, A., C. Casas, and J. M. Lema, "Degradation of Volatile Fatty Acids by Differently Enriched Methanogenic Cultures: Kinetics and Inhibition," Water Res., 29, 505 (1995).

Andrews, J. F. and S. P. Graef, "Dynamic Modeling and Simulation of the Anaerobic Digestion Process," In Anaerobic Biological Treatment Processes, Advances in Chemistry, Series 105, p. 126, American Chemical Society, Washington, D.C., U.S.A. (1971).
Angelidaki, I., L. Ellegaard, and B. Ahring, "A Comprehensive Model of Anaerobic Bioconversion of Complex Substrates to Biogas," Biotechnol. Bioeng., 63, 363 (1999).

APHA, "Standard Methods for the Examining of Waste and Wastewater, 20th ed." American Public Health Association, Washington D.C., U.S.A. (1998).

Babel, S., K. Fukushi, and B. Sitanrassamee, "Effect of Acid Speciation on Solid Waste Liquefaction in an Anaerobic Acid Digester," Water Res., 38, 2416 (2004).

Barredo, M. S. and L. M. Evison, "Effect of Propionate Toxicity on Methanogenic-Enriched Sludge, Methano-brevibacter Smithii, and Methanospirillium Hungatttti at Different pH Values," Appl. Environ. Microb., 57, 1764 (1991).

Batstone, D. J., J. Keller, I. Angelidaki, S. V. Kalyuzhnyi, S. G. Pavlostathis, A. Rozzi, W. T. M. Sanders, H. Siegrist, and V. A. Vavili, "Anaerobic Digestion Model No. 1 (ADM1), IWA Task Group for Mathematical Modeling of Anaerobic Digestion Processes," IWA Publishing, London, U.K. (2002).

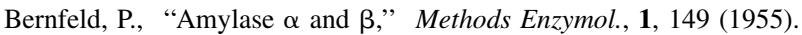

Cecchi, F., J. Mata-Alvarez, P. G. Traverso, F. Medici, and G. Fazzini, “A New Approach to the Kinetic Study of Anaerobic Degradation of the Organic Fraction of Municipal Solid Waste," Biomass, 23, 79 (1990).

Chen, Y. R. and A. G. Hashimoto, "Substrate Utilization Kinetic Model for Biological Treatment Process,” Biotechnol. Bioeng., 22, 2081 (1980).

Chen, B. Y., "Biological-Feasible Screening Strategy for Optimal Decolorization Strain to Diazo Evercion Red H-E7B," J. Chin. Inst. Chem. Engrs., 37, 355 (2006).

Chen, B. Y., H. L. Liu, Y. W. Chen, and Y. C. Cheng, "Synergistic Interactions of Binary Metal Toxicity to Indigenous Acidithiobacillus thiooxidans," $J$. Chin. Inst. Chem. Engrs., 37, 217 (2006).

Eastman, J. A. and J. F. Ferguson, "Solubilization of Particulate Organic Carbon during the Acid Phase of Anaerobic Digestion," J. Water Pollut. Contr. Fed., 53, 352 (1981).

Elefsiniotis, P., D. G. Wareham, and W. K. Oldham, "Particulate Organic Carbon Solubilization in an Acid-Phase Upflow Anaerobic Sludge Blanket System," Environ. Sci. Technol., 30, 1508 (1996).

Gallant, D. J., B. Bouchet, and P. M. Baldwin, "Microscopy of Starch: Evidence of a New Level of Granule Organization," Carbohyd. Polym., 32, 177 (1997).

Goel, R., T. Mino, H. Satoh, and T. Matsuo, "Comparison of Hydrolytic Enzyme Systems in Pure Culture and Activated Sludge under Different Electron Acceptor Conditions," Water Sci. Technol., 37, 335 (1998).

González, G., H. Urrutia, M. Roeckel, and E. Aspé, "Protein Hydrolysis under Anaerobic, Saline Conditions in Presence of Acetic Acid," J. Chem. Technol. Biotechnol., 80, 151 (2005).

Henze, M., "Anaerobic Wastewater," In Wastewater Treatment, SpringerVerlag, Berlin, Germany (1995).

Hobson, P. N., "The Kinetics of Anaerobic Digestion of Farm Wastes," $J$. Chem. Technol. Biotechnol., 33, 1 (1983).

Horiuchi, J., T. Shimizu, K. Tada, T. Kanno, and M. Kobayashi, "Selective Production of Organic Acids in Anaerobic Acid Reactor by pH Control," Bioresour. Technol., 82, 209 (2002).

Huang, S. Y., "Opportunities for Improving the Plant Cell Culture Processes for Secondary Metabolite Production," J. Chin. Inst. Chem. Engrs., 36, 561 (2005). 
Hwang, C. F., X. Y. Lin, and F. C. Yang, "Enhancing the Production of Enhancing the Production of $\gamma$-Glutamylcysteine by a Mutant Strain Derived from Saccharomyces cerevisiae BCRC 21727," J. Chin. Inst. Chem. Engrs., 36, 617 (2005).

Kao, P. M., P. J. Tsai, Y. C. Liu, and Y. C. Chang, "Optimization of Cultivation Conditions for the Production of Chitinase from Paenibacillus sp. CHEN1," J. Chin. Inst. Chem. Engrs., 37, 355 (2006).

Lan, Y. W., H. L. Liu, and Y. C. Cheng, "Optimized Physical Parameters for High Cell Density Cultivation of the Indigenous Thiobacillus thiooxidans by Response Surface Methodology," J. Chin. Inst. Chem. Engrs., 36, 243 (2005).

Lata, K., K. V. Rajeshwari, D. C. Pant, and V. V. N. Kishore, "Volatile Fatty Acid Production during Anaerobic Mesophilic Digestion of Tea and Vegetable Market Waste," World J. Microb. Biotechnol., 18, 589 (2002).

Lin, Y. C., S. C. Wu, and F. Mavituna, "Effects of Anaerobiosis on Alkaloid Production by Cell Suspension of Catharanthus roseus in Stirred-Tank Bioreactors," J. Chin. Inst. Chem. Engrs., 36, 639 (2005).

Liu, H. L., B. Y. Chen, Y. W. Lan, and Y. C. Cheng, "Improved Cultivation of the Indogenous Acidithibacillus thiooxidans BC1 by a Fed-Batch Process," J. Chin. Inst. Chem. Engrs., 35, 195 (2004).

Lowry, O. H., N. J. Rosebrough, A. L. Farr, and R. J. Randall, "Protein Measurements with the Folin Phenol Reagent," J. Biol. Chem., 193, 265 (1951).

McDonald, C. E. and L. L. Chen, "Lowry Modification of the Folin Reagent for Determination of Proteinase Activity," Anal. Biochem., 10, 175 (1965).

Miller, G. L., "Use of Dinitrosalicylic Acid Reagent for Determination of Reducing Sugar," Anal. Chem., 31, 426 (1956).

Mladenovska, Z. and B. K. Ahring, "Growth Kinetics of Thermophilic Methanosarcina spp. Isolated from Full-Scale Biogas Plants Treating Animal Manures,” FEMS Microbiol. Ecol., 31, 225 (2000).

Mösche, M. and H. J. Jördening, "Detection of Very Low Saturation Constants in Anaerobic Digestion: Influences of Calcium Carbonate Precipitation and pH,” Appl. Microbiol. Biotechnol., 49, 793 (1998).

Mösche, M. and H. J. Jördening, "Comparison of Different Models of Substrate and Product Inhibition in Anaerobic Digestion,” Water Res., 33, 2545 (1999).

Negri, E. D., J. Mata-Alvarez, C. Sans, and F. Cecchi, “A Mathematical Model of Volatile Fatty Acids (VFA) Production in a Plug-Flow Reactor Treating the Organic Fraction of the Municipal Solid Waste (MSW)," Water Sci. Technol., 27, 201 (1993).

$\mathrm{Ng}$, I. S. and S. W. Tsai, "Lipase Pretreatments on Enantioselective Hydrolysis of $(R, S)$-Arylpropionic Thioesters," J. Chin. Inst. Chem. Engrs., 36, 331 (2005).

Palenzuela-Rollón, A., "Anaerobic Digestion of Fish Processing Wastewater with Special Emphasis of Hydrolysis of Suspended Solids," PhD Thesis, Wageningen University, U.S.A. (1999).

Pind, P. F., I. Angelidaki, and B. K. Ahring, "Dynamics of the Anaerobic Process: Effects of Volatile Fatty Acids," Biotechnol. Bioeng., 82, 791 (2003a).
Pind, P. F., I. Angelidaki, and B. K. Ahring, "A New VFA Sensor Technique for Anaerobic Reactor Systems," Biotechnol. Bioeng., 82, 54 (2003b).

Roques, H., S. Yue, S. Saipanich, and B. Capdeville, "Is Monods approach adequate for the modelization of purification processes using biological treatment? Water Res., 16 (6), 839-847 (1982).

Rozzi, A. and W. Verstraete, "Calculation of Active Biomass and Sludge Production vs. Waste Composition in Anaerobic Contact Processes," Trib. Cebedeau, 34, 421 (1981).

Ruaan, R. C. and D. J. Yu, "Bio-Degradation of Pristane in Mixed Alkanes by a Mixed Culture Containing Nocardia corynebacteriodes," J. Chin. Inst. Chem. Engrs., 35, 651 (2004).

Sanders, W. T. M., M. Geerink, G. Zeeman, and G. Lettinga, "Anaerobic Hydrolysis Kinetics of Particulate Substrates," Water Sci. Technol., 41, 17 (2000).

Sanders, W. T. M., A. H. M. Veeken, G. Zeeman, and J. B. van Lier, "Analysis and Optimisation of the Anaerobic Digestion of the Organic Fraction of Municipal Solid Waste," In Biomethanization of the Organic Fraction of Municipal Solid Wastes, J. Mata-Alvarez, Ed., IWA Publishing, London, U.K. (2002).

Su, Y. H., Y. H. Ju, and Y. T. Chern, "Lipase-Catalyzed Synthesis of 2Arachidonylglycerol from Single-Cell Oil," J. Chin. Inst. Chem. Engrs., 37, 365 (2006).

Terashima, Y. and S. Lin, “On the Modeling of Microbiological Hydrolysis of Organic Solids," Water Sci. Technol., 42, 11 (2000).

Traverso, P., P. Pavan, D. Bolzonella, L. Innocenti, F. Cecchi, and J. Mata-Alvarez, "Acidogenic Fermentation of Source Separated Mixtures of Vegetables and Fruits Wasted from Supermarkets," Biodegradation, 11, 407 (2000).

Valentini, A., G. Garuti, A. Rozzi, and A. Tilche, "Anaerobic Degradation Kinetics of Particulate Organic Matter: A New Approach," Water Sci. Technol., 36, 239 (1997).

Vavilin, V. F., S. V. Rytov, and L. Y. Lokshina, "A Description of Hydrolysis Kinetics in Anaerobic Degradation of Particulate Organic Matter," Bioresour. Technol., 56, 229 (1996).

Veeken, A. and B. Hamelers, "Effect of Substrate-Seed Mixing and Leachate Recirculation on Solid State Digestion of Biowaste," Water Sci. Technol., 41, 255 (2000).

Veeken, A. S., H. Kalyuzhnyi, B. Scharff, and Hamelers, "Effect of pH and VFA on Hydrolysis of Organic Solid Waste," J. Environ. Eng., 126, 1076 (2000).

Zoetemeyer, R. J., J. C. van den Heuvel, and A. Cohen, "pH Influence on Acidogenic Dissimilation of Glucose in Anaerobic Digester," Water Res., 16, 303 (1982).

Zou, L. Q., P. J. He, L. M. Shao, and G. J. Li, "Influence of Recirculation Operations to the Output of Leachate in Initial Landfill Stage," J. Shanghai Jiaotong University, 37, 1784 (2003).

\title{
多醣顆粒物之酢素催化水解動力
}

\author{
何品晶 呂 凡 邵立明 潘修疆 \\ 上海同濟大學污染控制與資源化研究國家重點實驗室 \\ 李篤中 \\ 國立台灣大學化學工程學系
}

\begin{abstract}
摘 要

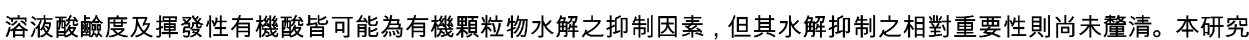
探討含大量多醣之馬鈴暑在固定 $\mathrm{pH}$ 值(5-9)與外加 $20 \mathrm{~g} \mathrm{~L}^{-1}$ 醋酸條件下之水解動力，發現 $\mathrm{pH}$ 值為較醋酸更重要之抑制因 素。簡化 Chen-Hashimoto model: $-\mathrm{d} S / \mathrm{d} t=K_{\mathrm{H}} S /\left(K_{\mathrm{S}}\left(S_{0}-S\right)+S\right)$ 可最適當描述抑制效應不明顯之馬鈴暑初期水解反應數據，而包 含三個抑制因子 $\left(\mathrm{H}^{+}, \mathrm{OH}^{-}\right.$, 總/未解離/解離醋酸 $)$之非競爭性抑制模型 $\left(K_{\mathrm{H}}=K_{\mathrm{H}}{ }^{0} /\left(1+\mathrm{I} / K_{\mathrm{I}}\right)\right)$ 則可描述後期抑制效應明顯時之 水解數據。
\end{abstract}

